In deze rubriek wordt het palet aan theoretische stromingen en theoretische oriëntaties in kwalitatieve onderzoeksbenaderingen belicht. Redacteur voor deze rubriek is Fijgje de Boer: fijgjedeboer@ chello.nl.

\title{
De analyse van levensverhalen: een psychologisch perspectief
}

\author{
Gerben Westerhof
}

Levensverhalen zijn voor een wetenschapper een gevaarlijk onderwerp. Want wat is er vluchtiger en onbetrouwbaarder dan dat? Elk levensverhaal is een uniek gegeven, dat voor iedere persoon anders is. Daarnaast is een levensverhaal gebonden aan de situatie waarin het wordt verteld en daarmee variabel. Sommige psychologen beweren zelfs dat mensen niet één groot verhaal over hun leven hebben, maar dat er alleen vele fragmenten zijn. Omdat het perspectief op het eigen leven verandert met het verstrijken van de tijd veranderen levensverhalen ook door de tijd. Een levensverhaal is daarom ook nooit af.

Vanwege de uniciteit, variabiliteit, fragmentatie en veranderlijkheid van levensverhalen vormen deze een moeilijk te grijpen fenomeen. Psychologen hebben zich er lange tijd verre van gehouden. Gedurende de afgelopen twintig jaar is er een groeiende interesse in het onderwerp ontstaan, zo zelfs dat gesproken wordt van 'narratieve psychologie'. Het boek Narrative Psychology, dat geredigeerd werd door Sarbin (1986), is een mijlpaal geweest, evenals het boek Acts of Meaning van Bruner (1990). Andere psychologen die ook genoemd dienen te worden, zijn Gergen en Gergen (1987), Harré en Van Langenhove (1999), McAdams (1996), Pennebaker (bijvoorbeeld Pennebaker \& Keough, 1999), Bamberg (1997) en Brockmeier (2000). In Nederland is de narratieve psychologie op de kaart gezet door Hermans en Kempen (1993) in hun boek The Dialogical Self en door het tijdschrift Psychologie \& Maatschappij in een themanummer hierover (1993, nummer 64). Meer recent brachten Bohlmeijer, Mies en Westerhof (2007) het eerste overzichtswerk uit over theorie, onderzoek en praktijk van levensverhalen in Nederland.

Veel van deze onderzoekers delen een kritiek op de meer traditionele psychologie. In de experimentele benadering die daarin centraal staat, gaat de aandacht met name uit naar cognitieve processen, die zich afspelen in de hersenen zonder dat mensen zich hiervan bewust zijn. Er wordt in deze benadering voorbijgegaan aan het vermogen van mensen om op hun eigen leven te reflecteren en daar betekenis aan te geven, wat eveneens als een cognitief proces kan worden gezien. Deze meer fenomenologische benadering van de mens staat in de narratieve psychologie juist centraal.

De aandacht die de afgelopen twee decennia is ontstaan voor de narratieve psychologie heeft (nog) niet geleid tot een eenheid in theorie en methode binnen deze benadering. Er worden verschillende manieren gebruikt om levensverhalen te verzamelen en te analyseren. Ik wil er hier een aantal uitlichten, waarbij ik me richt op de analyse van levens- 
verhalen en niet op het verzamelen ervan. Ik zal verschillende analysevormen illustreren aan de hand van een column die geschreven werd door Seth Gaaikema voor de website van het Jeroen Bosch Ziekenhuis, getiteld 'Ik ben een eigenzinnig patiënt':

'Toen ruim vier jaar geleden 2001 op zijn einde liep en ingewisseld werd voor een smetteloos nieuw jaar, werd ik getroffen door een hartaanval. In het Jeroen Bosch Ziekenhuis ben ik uitstekend behandeld en verzorgd, en als het ware opnieuw geboren.

Ieder mens gaat op zijn eigen manier om met een ziekte. Patiënt heb ik me nooit gevoeld. Ik ben een TIMF, een Tijdelijk Iets Minder Functionerende. Ik ben altijd wars geweest van het cultiveren van dit lichamelijk mankement. Want zo zie ik het: er was iets kapot en dat is gerepareerd. En nu eet ik alle pillen die ik moet eten, maar wil ik van de dokter niets horen over de conditie van mijn hart. Die informatie leidt namelijk tot niks. Ja, tot interpretaties en getob. Natuurlijk had ik angst, en heb ik angst. Iedereen heeft angst. Natuurlijk was ik bang voor de dood. Wie niet? Niemand begrijpt de dood, immers. We omringen ons met mensen, maar straks moeten we allemaal alleen door 'dat poortje heen'. Maar met de dood moet ieder mens zelf in het reine komen, dat staat los van ziekte.

Misschien kan ik als cabaretier wel makkelijker omgaan met mijn ziekte. Een cabaretier is optimaal zelfstandig. Dat moet wel! Ik ben getraind in zelfstandig denken, eigenzinnig zijn. Zo heb ik ook deze ziekte creatief opgelost. Altijd met de gedachte: het komt goed. Als ik liedjes of teksten schrijf en ik kijk naar een leeg computerscherm dan weet ik inmiddels dat er toch altijd wel iets nieuws komt. Waarom zou het stoppen? Waarom zou het leven stoppen?

'Het wordt na een hartaanval niet meer hetzelfde als het was', werd mij verteld toen ik het ziekenhuis verliet. Nee, het is zelfs beter dan vroeger! Je gooit namelijk alle rommel weg. Je doet niet meer aan de onzin, omdat je dat wat er echt toe doet helemaal wilt benutten.

Uiteraard kan ik alleen voor mezelf spreken en is elk mens en elke ziekte anders. Wel ben ik heel blij dat ik door mijn optredens voor de Hartstichting iets van mijn motto kan overbrengen. Een arts stelt een diagnose, geen prognose. Het is aan jou om eigenzinnig aan je toekomst te werken.'

De meest systematische en formele manier van het analyseren van levensverhalen is de zogeheten Linguistic Inquiry and Word Count (LIWC), die werd ontwikkeld door Pennebaker (zie bijvoorbeeld Pennebaker, Mayne \& Francis, 1997; zie ook www.liwc.net; zie voor een Nederlandse versie: Zijlstra, Van Middendorp, Van Meerveld \& Geenen, 2005). Pennebaker bestudeerde met name verhalen die mensen schreven in schrijfopdrachten naar aanleiding van gezondheidsproblemen. Middels de gecomputeriseerde methode van de LIWC deelt hij de woorden die gebruikt worden in verschillende categorieën in, zoals zelfreferenties (ik, me, zelf), sociale woorden (wij, vrienden), positieve emotiewoorden (geluk, lachen), negatieve emotiewoorden (verdriet, boosheid) en cognitieve woorden (omdat, reden, begrijpen, realiseren). Met name mensen die veel positieve affecten beschrijven, een gematigde hoeveelheid aan negatieve emoties laten zien en in de loop van een verhaal steeds meer cognitieve woorden gebruiken, ervaren een verbetering in gezondheidsklachten (Pennebaker, Mayne \& Francis, 1997). Wanneer een Engelse vertaling van de tekst van Seth Gaaikema met de onlineversie van de LIWC geanalyseerd 
wordt, blijkt dat hij ten opzichte van de persoonlijke teksten uit het bestand van Pennebaker relatief weinig zelfreferenties gebruikt, weinig positieve emotiewoorden, veel negatieve emotiewoorden en veel cognitieve woorden. Met name de verhouding tussen positieve en negatieve emotiewoorden is in dit verhaal nogal ongunstig. We zien echter wel een verloop van meer negatieve naar meer positieve emotiewoorden.

Een dergelijke formele analyse kent natuurlijk zijn beperkingen. Het feit dat Gaaikema de negatieve emoties juist sterk relativeert, door ze te veralgemeniseren en daarmee als het ware afstand te nemen van de impact van zijn hartaanval, blijft onopgemerkt. Veel psychologen kiezen daarom voor een meer interpretatieve benadering.

Een eerste aspect dat verschillende psychologen onderzoeken bij het analyseren van een levensverhaal is welke levensthema's er een rol in spelen. Deze worden vaak geïdentificeerd aan de hand van de verschillende aspecten die regelmatig terugkomen in een levensverhaal. Afhankelijk van de gebruikte theorie worden dit soort levensthema's ook wel heroes, imagoes, waarderingsgebieden of ik-posities genoemd (Hermans \& Kempen, 1993; McAdams, 1996). Ze bestaan doorgaans uit persoonlijke waarden, persoonlijkheidstrekken of rollen. In het verhaal van Gaaikema zien we minstens twee belangrijke posities terugkeren: zijn rol als patiënt, of TIMF zoals hij het zelf liever uitdrukt, en zijn rol als cabaretier.

Vaak worden de thema's verder geanalyseerd naar de motieven die erin tot uiting komen. Een veel onderzochte dualiteit is daarbij die tussen individualiteit en verbondenheid (Westerhof \& Bode, 2003), ook wel omschreven als agency en communion (Bakan, 1996) of als A-motief en Z-motief (Hermans \& Hermans-Jansen, 1995). Beide motieven worden gezien als grondmotieven van het menselijk bestaan. Ze komen dan ook in bijna elk levensverhaal voor, zij het in elk verhaal op een unieke manier. We zien dat Gaaikema in zijn rol als patiënt enerzijds zijn eigenheid benadrukt (elk mens en elke ziekte is anders) en anderzijds ook de verbondenheid met andere mensen (iedereen heeft angst). Zijn rol als cabaretier heeft zowel meer individuele betekenissen (als cabaretier kan ik makkelijker met mijn ziekte omgaan) als meer sociale betekenissen (ik kan door mijn optredens voor de Hartstichting iets van mijn motto overbrengen). Op deze wijze brengt zijn korte levensverhaal op een gebalanceerde manier de beide grondmotieven van het menselijk bestaan tot uitdrukking. Dat wordt meestal gezien als een teken van geestelijke gezondheid.

Een belangrijke vraag die gesteld kan worden bij de analyse van levensthema's is die naar de eenheid versus multipliciteit van het zelf. Een psycholoog als McAdams (1996) beargumenteert dat een levensverhaal helpt bij het scheppen van orde in het leven. Daarmee legt hij sterk de nadruk op het belang van coherentie in het levensverhaal, waarbij hij er overigens wel oog voor heeft dat een levensverhaal openheid dient te houden voor nieuwe ervaringen. Hermans en Kempen (1993) leggen echter juist meer de nadruk op het belang van multipliciteit. Zeker in de huidige samenleving waarin mensen een veelheid aan relaties en daarbij horende identiteiten hebben, is het bijna vanzelfsprekend dat de verhalen van mensen meerstemmig zijn. Deze meerstemmigheid kan ook weer behulpzaam zijn bij de aanpassing aan veranderende levensomstandighe- 
den: bepaalde thema's kunnen dan aan relevantie verliezen zonder dat het totale levensverhaal aan zin verliest.

Het verhaal van Gaaikema is in zekere zin meerstemmig, omdat hij zichzelf op verschillende wijzen beschrijft. Toch zien we ook dat de beide posities die in zijn verhaal van belang zijn met elkaar verknoopt zijn. In zekere zin vormen ze in zijn verhaal een coalitie, want door zijn eigenzinnigheid en zelfstandigheid als cabaretier kon hij naar eigen zeggen de ziekte creatief oplossen en zelfs deze oplossing uitdragen. Daarmee is zijn verhaal toch coherent.

Naast de vraag naar eenheid versus verscheidenheid wordt vaak de vraag gesteld naar continuiteit versus verandering. Het vóórkomen van bepaalde thema's in levensverhalen zegt nog weinig over het verloop van het levensverhaal. Om zicht te krijgen op continuiteit versus verandering wordt gebruikgemaakt van het begrip 'plot'. In de literatuurwetenschap worden verschillende typen verhalen onderscheiden, zoals de tragedische, komedische, romantiserende en ironiserende manier van verhalen (Frye, 1957). Gergen en Gergen (1987) maken hier gebruik van om levensverhalen te karakteriseren van mensen die geen literatoren zijn. In principe zijn er drie basisverhalen: een progressief narratief, een regressief narratief en een stabiel narratief. Deze kunnen samenkomen tot nieuwe verhaaltypen, zoals in het melodrama, een soap-achtige op- en neergaande verhaallijn met veel hoogte- en dieptepunten, die nooit echt tot een oplossing komen. Brockmeier (2000) onderscheidt een zestal typen:

- Lineair: een verhaal met een positief en progressief verloop.

- Circulair: een lineair model dat naar een bekende afloop toewerkt. Het levensverhaal wordt herschreven om eenheid en richting te herstellen naar de situatie van het heden.

- Cyclisch: een zich herhalend levensverhaal met een minder duidelijke richting.

- Spiraalvormig: een mix tussen lineair en cyclisch. Meer dan in het zich herhalende cyclische model zit hier, dankzij de lineaire component, wél weer richting in.

- Statisch: een verhaal dat stil is blijven staan in de tijd; het heeft eigenlijk geen duidelijke richting, omdat het blijft hangen bij een gebeurtenis van vroeger.

- Gefragmenteerd: een verhaal zonder duidelijk tijdsverloop, dat ook een eenheid mist.

Het verhaal van Seth Gaaikema begint met een onverwachte neergang, die contrasteert met de opening van het smetteloze nieuwe jaar. Daarna krijgt zijn levensverhaal een duidelijk progressief verloop. Het is opvallend dat hij zijn leven na de hartaanval als beter typeert dan ervoor: 'Je doet niet meer aan de onzin, omdat je dat wat er echt toe doet helemaal wilt benutten'. Dit geeft een andere duidelijke functie van het levensverhaal aan: naast het creëren van orde gaat het volgens McAdams (1996) om het creëren van richting (purpose) in het leven. Naarmate dit beter lukt en het verhaal een goede afloop heeft en een nieuwe opening naar de toekomst, is dit volgens McAdams (1996) beter voor de geestelijke gezondheid.

De besproken psychologische benaderingen hebben gemeen dat ze met name analyseren of een bepaalde inhoud en structuur van het levensverhaal bijdraagt aan de geestelijke gezondheid van een individu. Levensverhalen hebben volgens psychologen een 
belangrijke functie in het omgaan met problemen en in het creëren en in stand houden van welbevinden en zin in het leven. Een dergelijke functionalistische visie op levensverhalen geeft vat op de problemen van uniciteit, variabiliteit, fragmentatie en veranderlijkheid van het levensverhaal. Deze aspecten die een levensverhaal ongrijpbaar maken, zijn immers van ondergeschikt belang, als duidelijk is aan welke kenmerken een levensverhaal moet voldoen om mensen te helpen hun geestelijke gezondheid te bewaken.

We zien daarbij wel dat psychologen verschillende theoretische opvattingen hebben over de vraag welke kenmerken van een levensverhaal bevorderlijk zijn voor het ervaren van geestelijke gezondheid. Bij Pennebaker gaat het vooral om de expressie van emoties, bij McAdams om het creëren van eenheid en richting in het levensverhaal, bij Hermans om de balans tussen A-motief en Z-motief en om de meerstemmigheid van het levensverhaal. Soms staan theoretische opvattingen tegenover elkaar, zoals bij de vraag of eenheid of multipliciteit nu beter is voor de geestelijke gezondheid. Bestaande analyses blijven vaak gevalstudies die een bestaande theoretische opvatting verduidelijken (zoals die in het boek van McAdams, Josselson \& Lieblich, 2006). De analyse van levensverhalen heeft zich dus nog niet zover ontwikkeld dat een empirisch antwoord kan worden gegeven op tegengestelde theoretische opvattingen.

\section{Literatuur}

Bakan, D. (1966). The duality of human existence. Chicago: Rand McNally \& Company. Bamberg, G.W. (1997). Positioning between structure and performance. Journal of Narrative and Life History, 7: 335-342.

Bohlmeijer, E., Mies, L. \& Westerhof, G. (red.) (2007). De betekenis van levensverhalen. Houten: Bohn Stafleu van Loghum.

Brockmeier, J. (2000). Autobiographical time. Narrative Inquiry, 10: 51-73.

Bruner, J. (1990). Acts of meaning. Cambridge, MA: Harvard University Press.

Frye, N. (1957). Anatomy of criticism; Four essays. Princeton: Princeton University Press.

Gergen, K.J. \& Gergen, M.M. (1987). The self in temporal perspective. In: R.P. Abeles (Ed.), Life-span perspectives and social psychology. Hillsdale, NJ: Erlbaum: 121-137.

Harré, R. \& Langenhove, L. van (1999). Positioning theory: Moral contexts of intentional action. Massachusetts: Blackwell Publishers.

Hermans, H.J.M. \& Hermans-Jansen, E. (1995). Self-Narratives. The construction of meaning in psychotherapy. New York: Guilford Press.

Hermans, H.J.M. \& Kempen, H.J.G. (1993). The dialogical self: Meaning as movement. San Diego: Academic Press.

McAdams, D.P. (1996). Personality, modernity, and the storied self: A contemporary framework for studying persons. Psychological Inquiry, 7: 295-321.

McAdams, D.P., Josselson, R. \& Lieblich, A. (2006). Identity and story: Creating self in narrative. Washington, DC: American Psychological Association.

Pennebaker, J.W. \& Keough, K.A. (1999). Revealing, organizing and reorganizing the self in response to stress and emotion. In: R.J. Contrada \& R.D. Ashmore (Eds.) Self, social identity and physical health. New York: Oxford University Press, 101-121. 
Pennebaker, J.W., Mayne, T.J. \& Francis, M.E. (1997). Linguistic predictors of adaptive bereavement. Journal of Personality and Social Psychology, 72: 863-871.

Sarbin, T.R. (Ed.) (1986). Narrative psychology: The storied nature of human conduct. New York: Praeger.

Westerhof, G.J. \& Bode, C. (2004). The personal meaning of individuality and relatedness: Gender differences in middle and late adulthood. In: S.O. Daatland \& S. Biggs (Eds.) Ageing and diversity. Bristol: Policy Press: 29-44.

Zijlstra, H., Middendorp, H. van, Meerveld, T. van \& Geenen, R. (2005). Validiteit van de Nederlandse versie van de 'Linguistic Inquiry and Word Count' (LIWC): een experimentele studie onder vrouwelijke studenten. Nederlands Tijdschrift voor de Psychologie, 6o: $55-63$. 